\title{
Soupis prací Jany Pleskalové
}

V r. 2019 oslavila významné životní jubileum profesorka Filozofické fakulty MU Jana Pleskalová. Této události bylo věnováno první číslo 67. ročníku (2019) časopisu Linguistica Brunensia, v němž kromě pěti odborných článků s onomastickou tematikou vyšel rovněž medailon Jany Pleskalové. V následujícím textu se k zmíněnému výročí vracíme a publikujeme úplnou bibliografii tištěných prací prof. Jany Pleskalové do r. 2019. Seznam zkratek opakujících se periodik je uveden na konci textu.

1972

1. Pomístní jména na Ivančicku. ZMK ČSAV 13, 642-645.

2. Vinařství na Ivančicku. ZMK ČSAV 13, 426-432.

1974

3. Do Sokolnic, ale do Březnice. Rovnost, 13.7.

4. K pojetí modelu v pomístních jménech. ZMK ČSAV 15, 533-542; též In: MAJTÁN, Milan, ed. VI. slovenská onomastická konferencia. Bratislava: Veda, 39-46.

1975

5. K lexikální vybavenosti moravských anoikonym. ZMK ČSAV 16, 331-336.

6. O výzkumu místních a pomístních jmen. Universitas 8, 86-87.

1976

7. Onomastisches Seminar in Velké Karlovice. NI 29, 33-36.

8. Osobní jména v Krevní knize městečka Bojkovic. SPFFBU 25, A 24, 57-66.

1977

9. IV. onomastický seminář studentů. ZMK ČSAV 18, 655-657.

10. VII. slovenská onomastická konference. Universitas 10, 94-95.

1978

11. Jak se bude jmenovat? Rovnost, 29.11.

12. Jména brněnských ulic 1-4. Rovnost, 3. 9., 10. 9., 16. 9., 23. 9.

13. Ke vztahu pomístních jmen a nářečí na Moravě. Jazykovědné aktuality 15, 57-58.

14. K hranici mezi apelativy a proprii. ZMK ČSAV 19, 296-300. 
15. Onomastický seminář v Olomouci. Universitas 11, 88.

1979

16. Diplomové práce z onomastiky na pedagogické fakultě UJEP. Universitas 12, 62-63.

17. O pôvode a najstaršom vývine slovenčiny. Bratislava 1977. ZMK ČSAV 20, 87-91 [rec.: RužıČKA, Jozef, ed. O pôvode a najstaršom vývine slovenčiny. Stanislavov zborník, Bratislava 1977].

\section{0}

18. Pomístní jména typu Nezdařil(y), Přibylka (-ky). ZMK ČSAV 21, 561-568.

19. Pomístní jméno v jazykové komunikaci. In: MAjtán, Milan, ed. Spoločenské fungovanie vlastných mien. Bratislava: Veda, 81-84.

20. Zum Verhältnis von geographischen Termini und Flurnamen. NI 38, 27-32.

\section{1}

21. Geografija v nazvanijach. Moskva 1979. ZMK ČSAV 22, 133-136 [rec.: MurzAJEv, Eduard Makarovič. Geografija v nazvanijach, Moskva 1979].

22. K povaze lexikálních diferencí dialektových a onymických. In: GóRNowicz, Hubert, ed. Nazewnictwo obszarów językowo mieszanych. Wrocław: Ossolineum, 167-174.

\section{2}

23. Nářeční materiál v soupisech pomístních jmen. Vlastivědný věstník moravský 34, 72-74.

24. Perspektivy razvitija slavjanskoj onomastiki (sborník). Redakce A. V. Superanskaja, N. V. Podolskaja, Moskva 1980, nakladatelství Nauka, 396 stran. ZMK ČSAV 23, 73-82 [rec.: Superanskaja, Aleksandra Vasilevna - Podolskaja, Natalia Vladimirovna, ed. Perspektivy razvitija slavjanskoj onomastiki, Moskva 1980].

25. Příspěvek k zeměpisným diferencím v nářečí a mikrotoponymii. SPFFBU 31, A 30, 149154.

\section{3}

26. 83. stovka onomastických zpráv a poznámek. OZ ČSAV 24, 605-682 (kolektiv autorů; autorství 12 zpráv).

27. Anoikonymická a dialektologická mapa. In: MAJTán, Milan, ed. VIII. slovenská onomastická konferencia. Bratislava - Banská Bystrica - Prešov: Jazykovedný ústav L'udovíta Štúra SAV - Pedagogická fakulta v Banskej Bystrici - Pedagogická fakulta Univerzity Pavla Jozefa Šafárika v Prešove, 93-97.

28. J. Ivanov: Mestnite imena meždu Dolna Struma i Dolna Mesta. Sofija 1982. OZ ČSAV 24, 385-391 [rec.: Ivanov, Jordan N., ed. Mestnite imena meždu Dolna Struma i Dolna Města, Sofija 1982].

29. Ke vztahu pomístních jmen a nářečí na Moravě. Slavica Pragensia 19, Philologica 4-5, 129-132.

30. Socializace venkova a její odraz v pomístních jménech. In: ŠRÁmEK, Rudolf et al., eds. Onomastika jako společenská věda. Sborník prací Pedagogické fakulty v Ostravě. Praha: Státní pedagogické nakladatelství, 75-78. 


\section{4}

31. 5 drobných zpráv. OZ ČSAV 25, 135, 167, 168, 171, 172.

32. Die Kategorie der Possessivität in den Flurnamen Mährens. In: BıLY, Inge et al., eds. Resümees der Vorträge und Mitteilungen. XV. Internationaler Kongress für Namenforschung. Leipzig: Karl-Marx-Universität, 146.

33. Zpracování pomístních jmen Moravy a Slezska v diplomových pracích. In: DejMEK, Bohumír - ŠRÁMEK, Rudolf, eds. Onomastika jako společenská věda ve výuce a školské praxi. Hradec Králové: Pedagogická fakulta, 44-48.

34. Zur Klassifizierung der slawischen Flurnamen nach Modellen. Zeitschrift für Slawistik $29,80-89$.

\section{5}

35. Český sborník o onomastice jako společenské vědě. SaS 46(1), 76-78 [rec.: ŠrÁMEK, Rudolf et al., eds. Onomastika jako společenská věda, Ostrava 1983].

36. Die Kategorie der Possessivität in den Flurnamen Mährens. Zeitschrift für Slawistik 30, 867-870; též OZ ČSAV 26, 129-135.

37. K. Gutschmidt et al. Bibliographie slawistischer Publikationen aus der DDR 1978-1981. Slavia 54, 309-310 [rec.: GuTschмIDT, Karl et al. Bibliographie slawistischer Publikationen aus der Deutschen Demokratischen Republik 1978-1981, Berlin 1983].

\section{6}

38. První celostátní onomastický seminář. OZ ČSAV 27, 610-613.

39. Zur Entwicklung der früheren deutschen Mikrotoponymie in tschechischer Umgebung. In: Eichler, Ernst - WALther, Hans, eds. Onomastica Slavogermanica 15. Berlin: Akademie-Verlag, 157-161.

\section{7}

40. Flurnamen metaphorischen Ursprungs. NI 49, 25-31; též In: MAJTÁN, Milan, ed. IX. slovenská onomastická konferencia. Bratislava: Jazykovedný ústav L'udovíta Štúra SAV, 188-193.

\section{8}

41. Podíl pomístních jmen na tvorbě uličních názvů. In: Žıgo, Pavel, ed. Onomastika a škola 2 - Urbanonymia. Bratislava: Univerzita Komenského v Bratislave, 79-84.

42. Úloha frekvence při kartografování pomístních jmen. In: ZierHoffER, Karol, ed. V. ogólnopolska konferencja onomastyczna. Poznań: Wydawnictwo naukowe Uniwersytetu im. Adama Mickiewicza, 211-214.

43. Víceslovná pomístní jména v české anoikonymii. In: HomA, Edward. Onomastyka w dydaktyce szkolnej i spolecznej. Szczecin: Wydawnictwo Naukowe Uniwersytetu Szczecińskiego, 315-319.

\section{9}

44. Kdo jsou hrdobci. Rovnost, 3. 2.

45. Vývoj anoikonymie v oblastech nově osídlených po roce 1945. In: Majtán, Milan, ed. 
Aktuálne úlohy onomastiky z hl'adiska jazykovej politiky a jazykovej kultúry. Bratislava: Jazykovedný ústav L'udovíta Štúra SAV, 113-118.

\section{0}

46. VIII. celopolská konference. OZ ČSAV 31, 249-251.

47. Nová knížka o slovesných předponách. NŘ 73(4), 205-208 [rec.: UHER, František. Slovesné předpony, Brno 1987].

48. Seznam ulic některých měst v NDR. OZ ČSAV 31, 204.

49. Žı IGo, Pavol a kol. Lovinobaňa. OZ ČSAV 31, 236-237.

\section{1}

50. Jubileum (J. Balhara). Moravský večerník, 13. 6.

51. Strukturní typy pomístních jmen a charakter osídlení. In: MAJTÁN, Milan, ed.X. slovenská onomastická konferencia. Bratislava: Jazykovedný ústav L'udovíta Štúra SAV, 73-77.

\section{2}

52. Český jazykový atlas 1. Praha: Academia (kolektiv autorů; šifra Pl, mapy a komentáře: svatba 86-88; svatební obřad 88-89; chovat dítě 104; klouzat se 118-119, 121; klouzačka 120-122; šilhavý 136, 138-139; nehet 149-151; malíček 155, 157; kulhat 154-155; počkej 158; uzel 189; tkanička 189-190; podmáslí 226; řezník 236, 238; ledviny 242; sítko na mouku 254-255; drobty 272-274; povidla 274-276; konvička na mléko 284, 286-287; květináč 296, 298-300; truhlář 300; židle 300-302; koupelna 362; sud 366; stejný 375-378; střešní taška 376-378; špalek 389, 391; suk 389-391).

53. O tvoření českých pomístních jmen. $S a S$ 53(3), 193-200.

54. Tvoření pomístních jmen na Moravě a ve Slezsku. Jinočany: H\&H.

\section{3}

55. Nejstarší typy českých složených antroponym. SPFFBU 42, A 41, 87-98.

56. Slovotvorné adaptace německých pomístních jmen v české anoikonymii. Acta Universitatis Lodziensis, Folia linguistica 27, 221-224.

57. Zu den spezifischen Zeichen des onymischen Systems. In: BARTU゚ŇKovÁ, Jana - ŠRÁMEK, Rudolf, eds. Onymische Systeme. Hradec Králové: Gaudeamus, 35-37.

1994

58. Nejstarší typy českých prefigovaných antroponym. SPFFBU 43, A 42, 53-59.

\section{5}

59. Bibliografie prací Dušana Šlosara za léta 1953-1994. In: KARLík, Petr - Pleskalová, Jana - Rusínová, Zdenka, eds. Pocta Dušanu Šlosarovi. Boskovice: Albert, 9-28.

60. Jubileum Dušana Šlosara. In: KARLík, Petr - PleskalovÁ, Jana - Rusínová, Zdenka, eds. Pocta Dušanu Šlosarovi. Boskovice: Albert, 5-9.

61. K rozdílům mezi českými, moravskými a slezskými pomístními jmény. Čeština doma a ve světě $3(4), 248-251$.

62. Nejstarší česká antroponyma se sufixem -k. SPFFBU 44, A 43, 75-80. 
63. Nejstarší typy českých deadjektivních antroponym utvořených konverzí. In: KARLík, Petr - Pleskalová, Jana - Rusínová, Zdenka, eds. Pocta Dušanu Šlosarovi. Boskovice: Albert, 66-71.

64. Specifičnost bohemistiky jakožto lingvistiky mateřského jazyka. B: Diachronní disciplíny. In: Univerzity na prahu nového tisíciletí 2. Brno: Masarykova univerzita, 131-148 (kolektiv autorů).

65. Základní problémy rekonstrukce bohemik. $A O$ 36, 202-206.

\section{6}

66. Morphologie und Wortbildung der Flurnamen. Slavisch. In: EICHLER Ernst et al., eds. Namenforschung-Name Studies - Les noms propres. II. Berlin - New York: de Gruyter, 14471451.

67. O úloze tzv. hypokoristik v nejstarším období češtiny. NŘ 79(4), 204-206.

68. Význam nejstarších českých antroponym pro výuku češtiny. In: MAJTÁN, Milan - RuščÁk, František, eds. 12. slovenská onomastická konferencia a 6. seminár „Onomastika a škola“, zborník referátov. Bratislava: Prešovská univerzita v Prešově, 181-184.

1997

69. Český jazykový atlas 2. Praha: Academia (kolektiv autorů; šifra Pl, mapy a komentáře: ohryzek 68-70; rajské jablíčko 86-88; větší plochý kámen 289-290, 292-293; kamínek 294; hraniční kámen v polích 294-296; hromada kamení vybraného z pole 297-298, 300; údolí 299-300, 302; žleb 303; grúň 303; ráztoka 304; úvar 301, 304-305; grapa 301, 306; járek 307-308, 310; močál 311, 313-314; kaluž 316-318; obecní pozemek 318-320; draha 322; shora 338, 340-341; jáma 414-416).

70. Milan Majtán: Z lexiky slovenskej toponymie. AO 38, 190-192 [rec.: MAJTÁn, Milan. Z lexiky slovenskej toponymie, Bratislava 1996].

71. Nářečí. In: NeKudA, Vladimír et al., eds. Moravskobudějovicko, Jemnicko. Vlastivěda moravská 65. Brno: Muzejní a vlastivědná společnost v Brně, 351-362.

72. Nejstarší období češtiny ve světle osobních jmen. In: Rusinová, Eva, ed. Přednášky a besedy z XXX. běhu LŠSS. Brno: Masarykova univerzita, 102-106.

73. Publikace o pomístních jménech v Čechách. NŘ 80(1), 34-37 [rec.: OlivovÁ-NEzBEDovÁ, Libuše - KnAppová, Miloslava - MALEnínská, Jitka - MATúšová, Jana, eds. Pomístní jména v Čechách, o čem vypovídají jména polí, luk, lesů, hor, vod a cest, Praha 1995].

\section{8}

74. O tvoření českých antroponym tzv. krácením. In: JAKuś-BorkowA, Ewa - Nowik, Krystyna, eds. Najnowsze przemiany nazewnicze. Warszawa: Energeia, 323-326.

75. Tvoření nejstarších českých osobních jmen. Brno: Masarykova univerzita v Brně.

\section{9}

76. Česká pomístní jména v diachronním pohledu. AO 40, 186-195.

77. Českýjazykový atlas 3. Praha: Academia (kolektiv autorů; šifra Pl, mapy a komentáře: jetel 260-262; vojtěška 263-265; bramborový klíček 271-273; bramborová nat 276-278; ohníček na poli 278-280; raný 281-282; líšeň 298-300; pavuza 300-302; provaz na utažení 
pavuzy 302-305; zvrhnout 309-311; nádoba na dojení 407-409; řezačka 419-420; řezanka 419-421; vyhazovat hnůj z chléva 421-423; rozhazovat hnůj po poli 427-429; koza bez rohů 456-458).

78. K počátkům českého pravopisu. Listy filologické 122(3-4), 167-175.

\section{0}

79. K některým mechanismům a zákonitostem při kompozici slovanských antroponym. In: WARCHO£, Stefan, ed. Stowiańskie composita antroponimiczne. Rozprawy slawistyczne. Lublin: Uniwersytet Marii Curie-Skłodowskiej, 199-203.

80. K problémům onomastické terminologie. In: HLADKÁ, Zdeňka - KARLík, Petr, eds. Čeština - univerzália a specifika 2. Brno: Masarykova univerzita, 41-46.

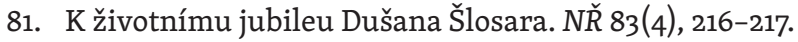

82. Nejstarší česká pomístní jména. In: OLivová-NezBedová, Libuše et al., eds. Onomastické práce IV. Praha: Ústav pro jazyk český AV ČR, 408-411.

83. O tzv. parasystému. SPFFBU 49, A 48, 41-46.

\section{1}

84. 225 let bohemistiky na vídeňské univerzitě. $N \check{R}$ 84(3), 151-153.

85. Niva v pomístních jménech na Moravě a ve Slezsku. In: ŘEHOŘEK, Vladimír - KvĚT, Radan, eds. Niva z multidisciplinárního pohledu. Brno: Př́ŕrodovědecká fakulta MU a Geodest Brno, 128-129.

86. Nový pohled na stará slovanská antroponyma. Slavia 70, 153-160.

87. Olivová-Nezbedová, L.; Malenínská, J. Slovník pomístních jmen v Čechách: úvodní svazek. SPFFBU 50, A 49, 255-257 [rec.: Olivová-NezBeDovÁ, Libuše - MALEnínSKÁ, Jitka, Slovník pomístních jmen v Čechách: úvodní svazek, Praha 2000].

88. Stará čeština pro nefilology. Brno: Masarykova univerzita (1. vydání).

89. Šrámek, Rudolf. Úvod do obecné onomastiky. SPFFBU 50, A 49, 227-229 [rec.: ŠRÁMEK, Rudolf. Úvod do obecné onomastiky, Brno 1999].

2002

90. Karlík, Petr - Nekula, Marek - Pleskalová, Jana, eds. Encyklopedický slovník češtiny. Praha: NLN - Nakladatelství Lidové noviny (kolektiv autorů; šifra JP, hesla: Antropolexém; Antroponymum; Areál onymický; Atlas onomastický; Čeština barokní (spoluautorství); Čeština 14. století (spoluautorství); Čeština humanistická (spoluautorství); Čeština obrozenská (spoluautorství); Čeština stará raná (spoluautorství); Deantroponymizace; Detoponymizace; Eponym; Exonymum; Formant onymický; Hypokoristikum; Jména vlastní - tř́dění; Jméno po chalupě; Jméno pomístní; Jméno vlastní asimilované; Jméno vlastní církevní; Jméno vlastní deapelativní; Jméno vlastní deminutivní; Jméno vlastní deonymické; Jméno vlastní eufemické; Jméno vlastní heraldické; Jméno vlastní hyperkorektní; Jméno vlastní kontrahované; Jméno vlastní metaforické; Jméno vlastní metonymické; Jméno vlastní místní služebné; Jméno vlastní osobní ochranné; Jméno vlastní přací; Jméno vlastní prímé; Jméno vlastní sakrální; Jméno vlastní standardizované; Jméno vlastní tautologické; Jméno vlastní zkratkové; Jméno vlastní živé; Klasifikace pomístních jmen modelová; Klasifikace vlastních jmen místních modelová; Kontext 
onymický; Kryptonym; Metoda malých typů; Objekt onymický; Objekt relační; Onomastika; Onymie; Otčestvo; Parasystém; Pole onymické; Proprializace; Př́jmení; Př́ijmí; Příznak onymický; Rekonstrukce onomastická; Soustava antroponymická dvoujmenná; Soustava antroponymická jednojmenná; Soustava antroponymická tř́ijmenná; Soustava antroponymická vícejmenná; Soustava českých vlastních jmen místních; Systém onymický; Topolexém; Toponymum; Toponymum honorifikační; Toponymum mytební; Tř́dění pomístních jmen významové; Urbanonymum).

91. RzetelsKa-Feleszko, Ewa et al., eds. Stowiańska onomastyka, encyklopedia, tom I. Warszawa - Kraków: Towarzystwo Naukowe Warszawskie (kolektiv autorů; heslo: Czechy - Antroponyma - Jména slovanská).

92. Vlastní jména osobní v češtině. In: Rusinová, Eva, ed. Přednášky a besedy z XXXV. běhu LŠSS. Brno: Masarykova univerzita, 128-135.

2003

93. Onomastika na Filozofické fakultě Masarykovy univerzity v Brně. Češtinár̆ 13, 3-6.

94. RzETELSKa-Feleszko, Ewa et al., eds. Stowiańska onomastyka, encyklopedia, tom II. Warszawa - Kraków: Towarzystwo Naukowe Warszawskie (kolektiv autorů; hesla: Pomístní jména na Moravě a ve Slezsku; Stav výzkumu pomístních jmen).

95. Stará čeština pro nefilology. Brno: Masarykova univerzita (přetisk 1. vydání).

96. Vývoj českého pravopisu. In: Rusinové, Eva, ed. Přednášky a besedy z XXXVI. běhu LŠSS. Brno: Masarykova univerzita, 102-111.

2004

97. Analogie v morfologickém vývoji českých a slovenských substantiv. In: ŽıGo, Pavel MatejKo, L'ubor, eds. BraSlav 2, 2003. Bratislava: Kartprint, 241-248.

98. Deminutivní pomístní jména v češtině. In: KarLík, Petr - Pleskalová, Jana, eds. Život s morfémy. Sborník studií na počest Z. Rusínové. Brno: Masarykova univerzita v Brně, 129-134.

99. Die ältesten tschechischen Wörter und ihre Bedeutung für die Anfangsperiode des Tschechischen. In: LehmanN, Volkmar - Udolph, Ludger, eds. Normen, Namen und Tendenzen in der Slavia. Festschrift für K. Gutschmidt zum 65. Geburtstag. München: Biblion Media, 397-401.

100. Jazykovědné zájmy Josefa Valentina Zlobického. Die sprachwissenschaftlichen Interessen Josef Valentin Zlobickýs. In: PLESKaLová, Jana - VINTR, Josef, eds. Vídeňský podíl na počátcích českého národního obrození. J. V. Zlobický (1743-1810) a současníci: život, dílo, korespondence. Wiener Anteil an den Anfängen der tschechischen nationalen Erneuerung.J. V. Zlobický (1743-1810) und Zeitgenossen: Leben, Werk, Korrespondenz. Praha: Academia, 61-69, 159-170.

101. Miloslava Knappová, Naše a cizí příjmení v současné češtině. Slavia 73(2), 208-209 [rec.: KNAPPové, Miloslava. Naše a cizí př́ijmení v současné češtině, Liberec 2002].

102. Velehradský rodák Josef Valentin Zlobický a jeho význam pro národní obrození. Acta universitatis Palackianae olomucensis. Studia Moravica I, 53-57 (s J. Vojtovou).

2005

103. Jan Hus a nabodeníčka. In: ČMEjRKovÁ, Světla - SvoBodová, Ivana, eds. Oratio et ratio. Sborník k životnímu jubileu Jiř́h Kro Krause. Praha: Ústav pro jazyk český AV ČR, 283-287. 
104. K základům českého pravopisu. In: RusınovÁ, Eva, ed. Přednášky a besedy z XXXVIII. běhu LŠSS. Brno: Masarykova univerzita, 107-111.

105. Několik poznámek k lékařské terminologii druhé poloviny 18. století. In: NEJEDLÝ, Petr VAJDLovÁ, Miloslava, eds. Verba et historia. Igoru Němcovi k 80. narozeninám. Praha: Ústav pro jazyk český AV ČR, 291-295.

106. Profesoru Dušanu Šlosarovi k narozeninám. SPFFBU 54, A 53, 196-198 (s P. Koskem a M. Křístkem).

\section{6}

107. Dějiny české jazykovědné bohemistiky. In: JANYšKová, Ilona - KARLÍková, Helena, eds. Studia etymologica Brunensia 3. Praha: NLN - Nakladatelství Lidové noviny, 343-347.

108. Grafická podoba staré češtiny. In: KRMíčKovÁ, Helena et al., eds. Querite primum regnum Dei. Sborník př́spěvků k poctě Jany Nechutové. Brno: Masarykova univerzita, 171-179.

109. Kapitoly z dějin české jazykovědné bohemistiky. In: Rusinová, Eva, ed. Přednášky a besedy z XXXIX. běhu LŠSS. Brno: Masarykova univerzita, 94-99.

\section{7}

110. Das tschechische Personennamensystem. In: Brendler, Andrea - Brendler, Silvio, eds. Europäische Personennamensysteme. Hamburg: Baar, 741-748.

111. Historická gramatika. In: Pleskalová, Jana et al., eds. Kapitoly z dějin české jazykovědné bohemistiky. Praha: Academia, 121-149.

112. Hypokoristika v češtině. In: Rusinová, Eva, ed. Přednášky a besedy z XL. běhu LŠSS. Brno: Masarykova univerzita, 150-156.

113. Nabodeníčka v české lingvistické terminologii. Slavica Slovaca 42(2), 147-151.

114. Pravopis - Od počátků do začátku národního obrození. In: PLESKALovÁ, Jana et al., eds. Kapitoly z dějin české jazykovědné bohemistiky. Praha: Academia, 499-515.

115. První svazek Slovníku pomístních jmen. NŘ 9o(1), 37-40 [rec.: MATúšová, Jana - OlivovÁ-Nezbedová, Libuše - Malenínská, Jitka - Harvalík, Milan - Mackovičová, Martina. Slovník pomístních jmen v Čechách I (A), Praha 2005].

116. Vývoj spisovné češtiny. In: Pleskalová, Jana et al., eds. Kapitoly z dějin české jazykovědné bohemistiky. Praha: Academia, 473-498.

\section{8}

117. Dílo Vlasty Pittnerové jako svědectví o pojmenovacích zvyklostech 19. stol. In: PASTYŘík, Svatopluk - VÍŠKA, Václav, eds. Onomastika a škola 8. Hradec Králové: Gaudeamus, 51-58.

118. Příspěvek k tvoření staročeských antroponym. In: JANYŠKová, Ilona - KaRLíkovÁ, Helena, eds. Varia Slavica. Sborník př́spěvků k 80. narozeninám Radoslava Večerky. Praha: NLN - Nakladatelství Lidové noviny, 171-174.

119. Vývoj dvoujmennosti v češtině. In: Rusınová, Eva, ed. Přednášky a besedy z XLI. běhu LŠSS. Brno: Masarykova univerzita, 167-177.

120. Vývoj pravopisu ve staré češtině. Bohemistyka 8, 321-338. 


\section{9}

121. Česká antroponyma v latinských textech 12.-13. století. Graeco-Latina Brunensia 14(1-2), 211-216.

122. K pojmenovacím zvyklostem v období 12.-13. století. In: HaRvaLík, Milan - MinÁŘovÁ, Eva - Tušková, Jana Marie, eds. Teoretické a komunikačni aspekty proprií. Prof. Rudolfu Šrámkovi k životnímu jubileu. Brno: Masarykova univerzita, 155-162.

123. MalinA, Jaroslav et al. Antropologický slovník. Brno: Cerm (kolektiv autorů; hesla: Abionymum; Antroponymum; Bionymum; Př́jimí).

124. Stará čeština pro nefilology. Brno: Masarykova univerzita (2. vydání).

\section{0}

125. Čornejová, Michaela. Tvoření nejstarších českých místních jmen: bohemika z 11.-13. století. Linguistica Brunensia 58(1-2), 379-382 [rec.: Čornejová, Michaela. Tvoření nejstarších českých místních jmen: bohemika z 11.-13. století, Brno 2009].

126. Historie oboru: jaký má smysl pro současnost? NŘ 93(4-5), 171-179 (s Petrem Karlíkem).

127. Hlavní typy českých př́jmení. In: Rusinová, Eva, ed. Přednášky a besedy ze XLIII. běhu LŠSS. Brno: Masarykova univerzita, 123-130.

128. Petr a Karlík v průběhu 12.-21. století na území dnešní České republiky. In: BičAN, Aleš - KlAšKa, Jan - MAcurová, Petra - ZMrzlíková, Jana, eds. Karlík a továrna na lingvistiku. Prof. Petru Karlíkovi k šedesátým narozeninám. Brno: Host - Masarykova univerzita, 388-393.

129. Staročeská hypokoristika a jejich praslovanské východisko. In: VALENTovÁ, Iveta HLADKÝ, Juraj, eds. Lexika slovenskej onymie. Bratislava - Trnava: Jazykovedný ústav L'udovíta Štúra SAV - Pedagogická fakulta Trnavskej univerzity - Veda, vydavatel'stvo Slovenskej akadémie vied, 312-318.

130. Vlastní jména osobní ve staré češtině. In: DAvid, Jaroslav - Čornejová, Michaela HARvalík, Milan, eds. Mnohotvárnost a specifičnost onomastiky. Ostrava - Praha: Ostravská univerzita v Ostravě - Ústav pro jazyk český AV ČR, v. v. i., 397-404.

131. Vývoj pravopisu ve staré češtině z pohledu dějin jazykovědné bohemistiky. In: ČoRNEJová, Michaela - Rychnovská, Lucie - Zemanová, Jana, eds. Dějiny českého pravopisu (do r. 1902). Sborník př́spěvků z mezinárodní konference Dějiny českého pravopisu. Brno: Host - Masarykova univerzita, 17-29.

2011

132. Vývoj vlastních jmen osobních v českých zemích v letech 1000-2010. Brno: Host - Masarykova univerzita.

2012

133. Prakticky odborné texty a jejich jazyk v kontextu střední češtiny. In: ČMEJRKová, Světla - Hoffmannová, Jana - KLímová, Jana, eds. Čeština v pohledu synchronním a diachronním. Stoleté kořeny Ústavu pro jazyk český. Praha: Karolinum, 213-217.

134. Př́ijmení typu Bednařík v češtině. Graeco-Latina Brunensia 17(2), 163-169.

135. Za prof. PhDr. Vincentem Blanárem, DrSc., dr. h. c. AO 53(1), 406-408. 
136. Přezdívky v češtině. In: Rusinová, Eva, ed. Přednášky a besedy ze XLVI. běhu LŠSS. Brno: Masarykova univerzita, 161-168.

\section{4}

137. Hlavní etapy vývoje antroponym v českých zemích. In: Rusinová, Eva, ed. Přednášky a besedy ze XLVII. ročníku LŠSS. Brno: Masarykova univerzita, 156-164.

138. Rudolf Šrámek: Retrográdní slovník místních jmen Moravy a Slezska. AO 55, 367-370 [rec.: ŠRÁMEK, Rudolf. Retrográdní slovník místních jmen Moravy a Slezska, Brno 2013]. 139. Vlastní jména osobní v češtině. Brno: Masarykova univerzita.

\section{5}

140. Antroponyma v Hájkově Kronice české. In: LinkA, Jan, ed. Na okraj Kroniky české. Praha: Academia, 27-36.

141. Česko-německé kontakty ve světle antroponymie českých zemí. In: TokAR, Silvo, ed. Slovanski jeziki v stiku z neslovanskimi: diahroni onomastični pogled. Slavic/Non-Slavic Language Contact in the Area of Diachronic Onomastics. Ljubljana: Znanstvena založba Filozofske fakultete. Linguistica 55, 149-160.

142. Hlavní etapy vývoje antroponym v českých zemích. In: Rusınová, Eva, ed. Přednášky a besedy ze XLVIII. ročníku LŠSS. Brno: Masarykova univerzita, 140-148.

143. K periodizaci vývoje antroponym. In: VALENTová, Iveta, ed. 19. slovenská onomastická konferencia. Zborník referátov. Bratislava: Veda, 105-108.

144. Profesoru Šlosarovi k půljubileu. Linguistica Brunensia 63(2), 85-86.

145. Vývoj přezdívek v češtině. In: BÁLlEKovÁ, Katarína - KRÁLIK, L'ubor - MúcsKová, Gabriela, eds. Jazykovedné štúdie XXXII. Prirodzený vývin jazyka a jazykové kontakty. Bratislava: Veda, 371-377.

146. Význam CDB pro hlubší poznání staré češtiny. Studia historica Brunensia 62(1), 25-32.

\section{6}

147. Karlík, Petr - NeKula, Marek - Pleskalová, Jana, eds. Nový encyklopedický slovník češtiny A-M, N-Ž. Praha: NLN - Nakladatelství Lidové noviny (kolektiv autorů; hesla: Abionymum; Antropolexém; Antroponymum; Bionymum; Deantroponymizace; Detoponymizace; Diakritický pravopis; Dvoujmenná antroponymická soustava; Eponym; Etnonymum; Fiktonym; Fytonymum; Hypokoristikum; Choronymum; Jednojmenná antroponymická soustava; Jméno po chalupě; Kryptonym; Křestní jméno; Metoda malých typů; Modelová klasifikace pomístních jmen; Modelová klasifikace vlastních jmen místních; Nabodeníčko; Nekrolog; Obrozenský pravopis; Oficiální osobní jméno; Onomastická rekonstrukce; Onomastický atlas; Onomastika; Onomastikon; Onymické pole; Onymický areál; Onymický formant; Onymický kontext; Onymický objekt; Onymický příznak; Onymický systém; Onymie; Onymizace; Parasystém; Pomístní jméno; Primitivní pravopis; Přezdívka; Př́jmí; Raná stará čeština; Relační objekt; Soustava českých vlastních jmen místních; Spřežkový pravopis; Strukturní typ slovanské oikonymie; Šlechtický predikát (spoluautorství); Topolexém; Toponymum; Transonymizace; Tř́íjmenná antroponymická soustava; Vícejmenná antroponymická soustava; Vlastní jména - třídění; 
Vlastní jméno asimilované; Vlastní jméno církevní; Vlastní jméno deapelativní; Vlastní jméno deminutivní; Vlastní jméno deonymické; Vlastní jméno eufemické; Vlastní jméno hyperkorektní; Vlastní jméno kontrahované; Vlastní jméno metaforické; Vlastní jméno metonymické; Vlastní jméno osobní ochranné; Vlastní jméno přací; Vlastní jméno přímé; Vlastní jméno sakrální; Vlastní jméno tautologické; Vlastní jméno zkratkové; Významové třídění pomístních jmen; Živé vlastní jméno).

148. Staročeské nekrology a jejich význam pro poznání nejstaršího období češtiny. In: RusiNovÁ, Eva, ed. Přednášky a besedy ze XLIX. ročníku Letní školy slovanských (bohemistických) studií. Brno: Masarykova univerzita, 175-184.

149. Toponyma jako kulturní hodnota a zdroj inspirace. In: DAvid, Jaroslav, ed. Toponyma: Kulturni dědictví a pamět míst. Ostrava: Ostravská univerzita v Ostravě, 58-68.

150. Významné jubileum Miloslavy Knappové. AO 57, 174-178.

2017

151. „Nejstarší období češtiny“ z pohledu Hájkovy Kroniky české a historických faktů. In: StLukA, Martin - ŠKrabAL, Michal, eds. Lifka a czban. Sborník př́spěvků k 70. narozeninám prof. Karla Kučery. Praha: NLN - Nakladatelství Lidové noviny, 10-16.

152. O praotci Čechovi a češtině. In: Rusinová, Eva, ed. Přednášky a besedy z L. (jubilejního) ročníku Letní školy slovanských (bohemistických) studií. Brno: Masarykova univerzita, 223234 .

2018

153. Bohuslav Balbín a jeho výklady vlastních jmen. In: ZAND, Gertude - NEWERKLA, Stefan M., eds. Jezuitská kultura $v$ českých zemích/Jesuitische Kultur in den böhmischen Ländern. Brno: Host, 119-135, 449 (s J. Vojtovou).

154. O praotci Čechovi a češtině. In: Rusinová, Eva, ed. Přednášky a besedy z LI. ročníku Letní školy slovanských (bohemistických) studiú. Brno: Masarykova univerzita, 217-228.

\section{9}

155. Jméno Jan v průběhu 12.-21. století na území dnešní České republiky. In: PAVLincová, Helena, ed. Filosofie jako životní cesta; ad honorem Jan Zouhar. Brno: Masarykova univerzita, 146-152.

156. Z nejstarší brněnské urbanonymie. In: RusinovÁ, Eva, ed. Přednášky a besedy z LII. ročníku Letní školy slovanských (bohemistických) studií. Brno: Masarykova univerzita, 222-228.

\section{Zkratky:}

$\mathrm{AO}=$ Acta onomastica

$\mathrm{NI}=$ Namenkundliche Informationen

$\mathrm{N} \check{\mathrm{R}}=$ Naše řeč

OZ ČSAV = Onomastický zpravodaj ČSAV

$\mathrm{SaS}=$ Slovo a slovesnost

SPFFBU = Sborník prací Filozofické fakulty brnènské univerzity

ZMK ČSAV = Zpravodaj Místopisné komise ČSAV 


\section{Michaela Boháčová}

Department of Czech Language

- $\quad$ Faculty of Arts, Masaryk University

Arna Nováka 1, 602 oo Brno

Czech Republic

mcornejova@phil.muni.cz

0

留

Toto dílo lze užít v souladu s licenčními podmínkami Creative Commons BY-NC-ND 4.0 Internationa (https://creativecommons.org/licenses/by-nc-nd/4.o/legalcode). Uvedené se nevztahuje na díla či prvky (např. obrazovou či fotografickou dokumentaci), které jsou v díle užity na základě smluvní licence nebo výjimky či omezení př́slušných práv. 